\title{
Manajemen Strategi : Kajian Teori Resource Based View
}

\author{
Rima Elya Dasuki \\ Institut Manajemen Koperasi Indonesia \\ rimadasuki@ikopin.ac.id
}

\begin{abstract}
ABSTRAK
Makalah ini bertujuan untuk menganalisis kerangka dari teori Resource Based View yang dikemukakan oleh para ahli dalam manajemen strategi, serta menguraikan kerangka SWOT terutama yang berkaitan dengan kekuatan dan kelemahan dengan cara mengidentifikasi apa yang menjadi kekuatan dan kapabilitas perusahaan serta menghindari kelemahan yang dimiliki untuk keunggulan bersaing dan diharapkan dapat menguraikan konsep tentang Resource Based View dan menganalisis perkembangan teori Resource Based View dalam manajemen strategi dan menganalisis lingkungan internal dilihat dari sudut kekuatan dan kelemahan yang akan membantu perusahaan agar mampu mengambil keuntungan dari peluang-peluang yang ada dan mampu menghindari ancaman yang mungkin timbul, serta menganalisis kapabilitas perusahaan dimana akan mempengaruhi produk akhir yang meliputi skill, kapasitas dan sumber daya yang dinamis.Metode penelitian yang digunakan adalah berdasarkan dari pendekatan historis dan literature review dari pendapat para ahli yang membahas teori Resource Based View, baik yang bersifat fisik maupun non fisik dalam kaitannya dengan kapabilitas dan kompetensi dalam menciptakan daya saing yang unggul,dengan kajian utama berdasarkan pendapat ahli management strategic Mahoney Joseph T, J. Rajendran Pandian,1992. Pada makalah ini akan diarahkan kepada analisa berbagai pendapat para ahli ekonomi mengenai kerangka sumber daya yang akan menghasilkan suatu kapabilitas yakni keahlian-keahlian yang ada pada setiap individu., serta menganalisa keunikan dari sumber daya yang dimiliki baik yang bersifat fisik dan intangible asset akan mendukung keunggulan bersaing dari suatu perusahaan
\end{abstract}

Kata Kunci : Resource Based View, Kapabilitas, Kompetensi, Keunggulan bersaing

\begin{abstract}
This paper aims to analyze the framework of the Resource Based View theory put forward by experts in strategic management, as well as to describe the SWOT framework, especially those related to strengths and weaknesses by identifying what are the strengths and capabilities of the company and avoiding weaknesses for competitive advantage. and is expected to be able to describe the concept of Resource Based View and analyze the development of Resource Based View theory in strategic management, and analyze the internal environment from the point of view of strengths and weaknesses that will help the company to be able to take advantage of existing opportunities and be able to avoid possible threats. arise, and analyze the company's capabilities that will affect the final product which includes dynamic skills, capacities, and resources. The research method used is based on a historical approach and literature review from the opinions of experts who discuss the theory of Resource Based View, both physical and non-physical in relation to capabilities and competencies in creating superior competitiveness, with the main study based on the opinion of strategic management experts. Mahoney Joseph T, J. Rajendran Pandian, 1992. This paper will be directed to the analysis of various opinions of economists regarding the resource framework that will produce a capability, namely the skills that exist in each individual. competitive of a company
\end{abstract}

Keyword: advantage Resource Based View, Capability, Competence, Competitive advantage

\section{PENDAHULUAN}

Pendekatan ekonomi klasik ini menarik perhatian sejumlah peneliti sehingga menimbulkan adanya dialog dari berbagai perspektif. The Resource Based View merupakan ilmu manajemen yang baik,karena mendorong adanya perbincangan dalam bidang manajemen strategi, yakni good science is good conversation Studi dari keunggulan bersaing merupakan salah satu dari pembahasan dari Resource Based View. 
Berdasarkan studi dari J. Mahoney dan J.Rajendran, secara garis besar pembahasan Resource Based Theory ini dapat ditinjau dari tiga perspektif:

Pertama, tinjauan berdasarkan konsep manajemen strategi yang meliputi keunggulan bersaing sebagai dasar dari Resource Based View, termasuk teori yang berhubungan dengan return dan kinerja di bidang strategi.

Kedua pendekatan Resource Based View di dalam organisasi ekonomi yaitu yang berkaitan dengan positive agency theory, property right,transaction cost economic and evolutionary economi.

Ketiga, Pendekatan Resource Based Value yang berorientasi kepada analisis organisasi industri.

Berkaitan dengan Analisa Lingkungan Internal maka pembahasan makalah ini lebih difokuskan kepada halhal yang berkaitan dengan kekuatan dan kelemahan dari manajemen strategi dalam mempertahankan keunggulan bersaing. Dalam menganalisis lingkungan internal dapat dilihat dari fungsi bisnis, Value Chain dan intangible asset.

Tujuan dari dari makalah ini adalah untuk menganalisis kerangka dari teori Resource Based View terutama yang berkaitan dengan kekuatan dan kelemahan, dengan cara mengidentifikasi apa yang menjadi kekuatan dan kapabilitas perusahaan serta menghindari kelemahan yang dimiliki untuk keunggulan bersaing Studi ini diharapkan dapat memberikan gambaran mengenai karakteristik dari pendekatan sumber daya yang dapat memberikan kontribusi dalam praktek manajemen strategi dan meningkatkan kapabilitas serta kompetensi dari perusahaan untuk meningkatkan keunggulan bersaing melalui pendayagunaan sumber sumber daya baik yang bersifat fisik maupun non fisik.

Prinsip Resource Based View adalah berkaitan dengan teori keunggulan bersaing. Untuk memperoleh sustainable competitive advantage mengharuskan perusahaan untuk memperoleh economic rents atau return. Selanjutnya akan memfokuskan bagaimana perusahaan memperoleh dan mempertahankan keunggulan. Hal ini juga menjawab pertanyaan mengenai hal pokok apa yang harus dilakukan terhadap sumber dayanya agar mampu bersaing. Karakteristik sumber daya yang mempunyai keunggulan dapat diperoleh dengan jika sumber daya tersebut mempunyai nilai yang unik, sulit untuk ditiru dan sulit mendapatkan barang substitusinya.The RBV merupakan pilihan dari strategi yang akan dilakukan untuk mengembangkan dan maksimalisasi return.
Perkembangan Resource Based View selama beberapa dekade ini telah memberi kontribusi di bidang ekonomi dan manajemen strategis baik yang berusaha untuk memperbaiki konsep RBV atau menggunakannya sebagai kerangka kerja untuk menangani pertanyaan yang konseptual dan empiris.

Kontribusi utama dari pandangan berbasis sumber daya perusahaan merupakan teori Advantage competitive. Logika dasarnya adalah dimulai dengan asumsi bahwa hasil yang diinginkan dari upaya manajerial dalam perusahaan adalah keuntungan kompetitif yang berkelanjutan. Mencapai keunggulan kompetitif yang berkelanjutan, memungkinkan perusahaan untuk memperoleh 'economic rent' atau di atas rata-rata return. Hal ini memfokuskan perhatian pada bagaimana perusahaan mencapai dan mempertahankan keunggulan.

RBV ini berpendapat bahwa untuk mempertahankan keunggulan bersaing terletak pada kepemilikan sumber daya kunci tertentu, yaitu sumber daya yang memiliki ciri-ciri seperti nilai, hambatan untuk duplikasi. Keunggulan dapat diperoleh jika perusahaan secara efektif mengoptimalkan sumber daya ini. RBV menekankan pilihan strategis, mengoptimalkan sumber daya manusia, mengelola, mengidentifikasi, mengembangkan dan menggunakan sumber daya utama untuk memaksimalkan nilai perusahaan.

Edith Penrose's memunculkan teori pertumbuhan perusahaan yang memberikan argumen dari pandangan berbasis sumber daya dalam literatur ekonomi. Dia mencatat bahwa, suatu perusahaan bukan hanya satu unit administrasi, namun merupakan kumpulan sumber daya produktif. Kutipan di atas menyoroti dimensi penting dari pandangan berbasis sumber daya pikiran selama dekade terakhir, yaitu, peran manajer dalam pengembangan dan penyebaran sumberdaya .Penrose juga menyatakan bahwa sumber daya tidak hanya bersifat fisik tapi juga dapat merupakan non fisik (Rugman \& Verbeke, 2002) dengan kata lain, jasa yang dihasilkan oleh sumber daya adalah fungsi dari sumber daya yang digunakan, dalam arti bahwa sumber daya yang sama bila digunakan untuk tujuan yang berbeda atau dengan cara yang berbeda atau dikombinasikan dengan sumbersumber lain menyediakan layanan yang berbeda.

Penrose melihat perbedaan ini sebagai sumber keunikan setiap individu perusahaan dan merupakan perbedaan yang memiliki banyak kesejajaran dengan pemisahan sumber daya dan kemampuan yang mencirikan sebagian besar literatur tentang strategi (Joseph T Mahoney, 1992) Penrose berpendapat 
bahwa 'internal' sumber daya memfasilitasi dan membatasi arah perluasan perusahaan yang berlaku untuk perluasan eksternal seperti meningkatnya permintaan dan perubahan dalam teknologi, dll Berdasarkan pemikiran para ahli ekonomi diatas menggambarkan bahwa teori Resource Based View merupakan ilmu yang menarik untuk dianalisis.

Keberhasilan atau kegagalan suatu organisasi sangat tergantung kepada faktor sumber daya. Keunggulan bersaing suatu organisasi merupakan kekuatan perusahaan yang sangat didukung oleh sumber daya yang baik dalam kerangka sistem pengelolaan sumber daya yang bersifat strategic, integrated, saling berhubungan dan unity. Persaingan merupakan inti keberhasilan atau kegagalan perusahaan. Persaingan memerlukan ketepatan aktivitas dari suatu perusahaan seperti inovasi dan budaya kerja yang baik.

Berkaitan dengan pendekatan teori Resource Based View dari berbagai pendapat para ahli, teori Resource Based View merupakan kekayaan milik perusahaan baik yang bersifat fisik maupun non fisik, dimana untuk dapat mencapai keunggulan bersaing yang berkelanjutan maka sumber daya haruslah mempunyai nilai tambah ekonomis yang mempunyai karakteristik sulit untuk ditiru dan tidak mudah untuk digantikan.

\section{Pembahasan Dan Analisis Teori Resource Based View.}

Menurut pendekatan RBV, perusahaan merupakan sekumpulan sumber daya strategis dan produktif yang unik, langka, kompleks, saling melengkapi dan sulit untuk ditiru para pesaing yang dapat dimanfaatkan sebagai elemen untuk mempertahankan strategi bersaingnya. Keunggulan bersaing sebuah perusahaan harus didasarkan pada sumberdaya khusus yang menjadi penghalang aktivitas peniruan dan ancaman dari produk pengganti atau jasa perusahaan. Meningkatnya tekanan persaingan dapat menurunkan keunggulan bersaing perusahaan. Hal ini mengindikasikan bahwa bagi sebuah perusahaan, agar tetap bertahan hidup di tengah tekanan persaingan yang semakin tajam, perusahaan harus mengambil tindakan yang dapat mempertahankan dan memperkuat kompetensinya yang unik (Joseph T Mahoney, 1992). Sumberdaya dan kompetensi perusahaan dapat ditempatkan dalam sebuah kontinum untuk melihat bahwa sumberdaya dan kompetensi tersebut tahan lama dan tidak dapat ditiru. Berdasarkan studi dari J.Mahoney dan J.Rajendran,secara garis besar pembahasan Resource Based View Theory ini dapat ditinjau dari tiga perspektif:
Pertama, tinjauan berdasarkan konsep manajemen strategi;yang meliputi keunggulan bersaing sebagai dasar dari Resource Based View,termasuk teori yang berhubungan dengan return dan kinerja di bidang strategi.

Kedua, pendekatan Resource Based View di dalam organisasi ekonomi yaitu yang berkaitan dengan positive agency theory, property right, transaction cost economic dan evolutionary economic.

Ketiga, pendekatan Resource Based Value yang berorientasi kepada analisis organisasi industri.

Strategi dapat dilihat sebagai sebuah continuing search for rent, dimana rent diartikan sebagai pendapatan atas kelebihan dari opportunity cost atas sumber daya pemilik. Sumber daya dapat diklasifikasikan dalam beberapa hal contohnya tanah, peralatan, tenaga kerja (termasuk kapabilitas dan pengetahuan karyawan) dan capital (organisasi, tangible dan intangible) serta hal lain yang memberikan nilai guna (Kor \& Mahoney, 2004).

Pertama, rent dapat diperoleh dengan memiliki sumber daya bernilai yang langka.Sumber daya ini menghasilkan apa yang disebut Ricardian rents termasuk kepemilikan dari tanah yang berharga, keunggulan lokasi, paten dan copyright.

Kedua, monopoly rent dapat diperoleh dengan proteksi pemerintah atau dengan collusive arrangements dimana adanya hambatan dari persaingan potensial yang tinggi (Bain,1968).

Ketiga, entrepreneurial (Schumpeterian) rent dapat diperoleh dengan pengambilan resiko dan kemampuan entrepreneur dalam lingkungan yang komplek / penuh ketidakpastian.

Pandangan berdasarkan sumber daya berkembang dalam manajemen strategi untuk menjelaskan bagaimana perusahaan memperoleh rents. Perusahaan memilih strategi untuk memperoleh rents tergantung kepada kapabilitas sumber daya mereka. Organisasi dengan kapabilitas untuk mengevaluasi secara efektif posisi sumber daya dalam hal kekuatan dan kelemahan mempunyai dasar yang kuat untuk keunggulan bersaing. Teori ini membawa kita untuk menguraikan kerangka SWOT dengan mengidentifikasi benar-benar apa yang menjadi kekuatan dan kapabilitas perusahaan untuk keunggulan strategik (Md Husin \& Haron, 2020).

Perusahaan yang mempunyai keunikan kapabilitas dalam kemampuan teknis dan manajerial merupakan sumber daya yang penting untuk dapat mempertahankan keunggulan bersaing. Secara khusus, keunggulan yang berbeda/unik dan kegiatan 
rutin organisasi yang unggul dalam satu atau lebih rantai nilai memungkinkan perusahaan mendapatkan rents dari keunggulan bersaing. Penrose mengatakan bahwa ketersediaan potensial dari sumber daya akan memberikan setiap perusahaan karakter yang unik. Sebagai contoh top management dari suatu perusahaan jika mempunyai sumber daya yang memadai dan sumber daya yang berbeda/unik akan memberikan kontribusi perolehan keuntungan perusahaan. Perusahaan memperoleh rents bukan karena mempunyai sumber daya yang lebih baik, tetapi lebih dikarenakan kompetensi yang unggul dalam penggunaan sumber daya. Pemikiran ini menyatakan bahwa sumber daya perusahaan saat ini dipengaruhi oleh persepsi manajerial dan karenanya arah dari pertumbuhan adalah preposisi kognitif yang menguatkan alasan ekonomi bahwa sumber daya akan dipengaruhi oleh diversifikasi (Abu Bakar \& Ahmad, 2010).

Tinjauan dari aspek sumber daya berkontribusi besar terhadap aliran dari penelitian strategi diversifikasi dalam empat bidang ;

Pertama, Pendekatan RBV mempertimbangkan keterbatasan dari pertumbuhan diversifikasi (melalui pertumbuhan internal dan merger serta akuisisi).

Kedua, pendekatan RBV mempertimbangkan pentingnya motivasi dalam diversifikasi.

Ketiga, pendekatan RBV memberikan perspektif teoritikal untuk memprediksi arah dari diversifikasi.

Keempat, pendekatan RBV menyediakan sebuah teori rasional untuk memprediksi kinerja yang tinggi untuk kategori tertentu yang berhubungan dengan diversifikasi.

Pada dasarnya ada keterbatasan sumber daya dari perusahaan berkaitan dengan pasar yang akan dimasuki dan keuntungan yang diharapkan (PertusaOrtega et al., 2010).

Keterbatasan sumber daya ini meliputi :

1. Terbatasnya /kekurangan tenaga kerja dan input fisik

2. Keterbatasan keuangan

3. Langkanya kesempatan investasi yang tepat

4. Langkanya kapasitas manajemen yang efisien

Diversifikasi teori dari sumber daya menyatakan bahwa dampak terhadap perusahaan mungkin ada dalam bentuk yang fokus, alasannya;

1. Diversifikasi yang luas membuat perusahaan kurang fokus
2. Sumber daya yang ada akan berkurang nilainya ketika ditransfer ke pasar yang tidak mirip dengan aslinya

The Resource Based Value dari keunggulan kompetitif juga dapat dianalisis dalam konteks evolutionary. Keunggulan kompetensi perusahaan dapat didefinisikan sebagai sekumpulan peraturan yang rutin digunakan oleh top manajemen.Keputusan manajemen di masa lalu dan peraturan dalam pengambilan keputusan merupakan hal dasar yang akan mempengaruhi perusahaan. Pendekatan RBV juga diselaraskan dengan teori lain di dalam paradigma organisasi ekonomi. The RBV berhubungan dengan property right semenjak property right digambarkan sebagai sumber daya yang bernilai, property right menjadi lebih presisi. Pada akhirnya teori RBV berhubungan dengan teori transaction cost karena kombinasi sumber daya akan dipengaruhi oleh transaction cost. Sumber daya yang bernilai sulit untuk ditiru dan disubstitusi sehingga memungkinkan perusahaan memperoleh dan mempertahankan rents. Sustainability dari rents adalah barriers to imitation'.

\section{Perkembangan Teori Resource Based View}

Perusahaan yang sukses adalah perusahaan yang berfokus pada peningkatan kompetensi, yang digunakan dengan cara-cara baru dan inovatif untuk mencapai tujuan. Perhatian utama perusahaan adalah menggunakan sumber dayanya dalam cara-cara yang menantang dan kreatif untuk membangun kompetensi inti.

Kompetensi memiliki pengaruh yang kuat terhadap kinerja perusahaan. Perusahaan yang memiliki tim manajemen dengan keahlian optimal dan metode bersaing yang didasarkan pada kompetensi inti akan mampu mencapai kinerja yang lebih tinggi dibandingkan perusahaan lain yang tidak dapat melakukannya. Dengan kompetensi superior akan memungkinkan perusahaan memperoleh informasi apa yang dibutuhkan dan diinginkan oleh pelanggannya.

Perusahaan yang memiliki karyawan dengan kompetensi yang tinggi, akan lebih mampu menyediakan produk dan layanan yang sesuai dengan kebutuhan dan keinginan pelanggan. Oleh karena itu, perusahaan dengan kompetensi superior dapat memperoleh keunggulan bersaing yang berkesinambungan dan selanjutnya dapat meningkatkan kinerjanya. Agar dapat mempertahankan keunggulan bersaing tersebut, kompetensi yang dimiliki perusahaan haruslah mampu menambah nilai, langka, sulit ditiru, dan sulit 
digantikan. Kompetensi yang tidak mudah ditiru merupakan inti dari teori Resource Based, dan sentral pemahaman mengenai keunggulan bersaing yang berkelanjutan.

Kompetensi yang sulit ditiru memiliki hubungan yang positif dengan kinerja. Kompetensi dilindungi dari peniruan dengan berbagai cara. Kompetensi yang berasal dari faktor seperti lokasi yang strategis, kepemilikan hak cipta, akan melindungi sumberdaya bernilai tersebut dari tindakan peniruan oleh pesaing. Sumberdaya yang bersifat socially complex, seperti reputasi yang baik dan kepercayaan merupakan sumberdaya yang membutuhkan waktu dan biaya yang tinggi untuk ditiru. Dalam perjalanannya teori Resource Based Value berkembang dan salah satunya adalah masuknya Knowledge Management (KM) sebagai salah satu variabel dari Resource Based View, mendefinisikan. Knowledge Management adalah sebuah strategi untuk mendapatkan pengetahuan yang benar kepada orang yang tepat pada saat yang tepat dan membantu orang-orang berbagi dan menaruh informasi ke dalam tindakan dengan cara-cara yang akan meningkatkan kinerja organisasi. Knowledge Management dapat dianggap sebagai proses desain yang disengaja, peralatan, struktur, dengan maksud untuk meningkatkan, memperbarui, berbagi atau meningkatkan penggunaan pengetahuan terwakili dalam salah satu dari tiga unsur (struktural, manusia, dan sosial) dari modal intelektual. Identitas merek dan modal sosial adalah sumber daya non-ekonomi yang dapat membantu untuk bersaing dalam lingkungan yang semakin kompetitif. RBV menyatakan bahwa untuk memberikan keunggulan kompetitif, sumber daya perusahaan harus punya value, unik, dan tidak dapat diganti. Studi kualitatif ini mendukung konseptualisasi identitas merek dan modal sosial sebagai sumber daya tersebut. (Runyan et al., 2007).

Knowledge Management mendorong individu untuk mengkomunikasikan pengetahuan mereka dengan menciptakan lingkungan dan sistem untuk me pengorganisasian, dan berbagi pengetahuan di seluruh perusahaan. Knowledge Management memiliki dua tujuan utama: (1) untuk membuat organisasi bertindak secerdas mungkin untuk mengamankan kelangsungan hidup dan keberhasilan secara keseluruhan, dan (2) untuk menyadari nilai terbaik dari aset pengetahuan Tujuan pengetahuan manajemen, dengan demikian, adalah untuk meningkatkan sebuah aset intelektual organisasi dalam mempertahankan keunggulan kompetitif(Portillo-Tarragona, 2018).

Melalui eksplorasi empiris, sumber daya perusahaan telah diklasifikasikan menjadi enam sumber daya strategis yaitu: (1) fisik; (2) reputasi; (3) organisasi; (4) keuangan; (5) intelektual manusia; dan (6) teknologi. Orientasi kewirausahaan dianggap sebagai sumber daya intelektual manusia karena perusahaan berusaha untuk mendapatkan keunggulan kompetitif dan mengadopsi inovasi teknologi dan non-teknologi (Abu Bakar \& Ahmad, 2010)

Keputusan tentang desain organisasi dan strategi bersaing suatu perusahaan sangat penting untuk memperoleh keunggulan bersaing dan untuk meningkatkan kinerja perusahaan. Hubungan antara struktur organisasi, strategi bersaing, dan kinerja perusahaan biasanya dianalisis dengan menggunakan pendekatan kontingensi. (Pertusa-Ortega et al., 2010). Keunggulan kompetitif harus dijaga agar dapat terjaga kelanjutan. (Brahma \& Chakraborty, 2011). Analisis strategis adalah fitur kunci dari manajemen strategis (Andersen, 2010). Salah satu arah penting penelitian adalah isu-isu manajemen strategis organisasi publik dan mencari solusi untuk meningkatkan efisiensi mereka di bidang itu, terutama di lingkungan yang semakin dinamis (Szymaniec- Mlicka, 2014)

Kinerja organisasi sangat bergantung pada lingkungannya, oleh karena itu strategi organisasi harus merupakan hasil dari posisi kompetitif organisasi dalam industri. (Frączkiewicz-Wronka \& Szymaniec, 2012)

Kontribusi utama dari pandangan berbasis sumber daya manajemen strategis mungkin kemampuannya untuk menyatukan beberapa untaian penelitian di bidang ekonomi, organisasi industri, ilmu organisasi, dan strategi itu sendiri. (Rugman \& Verbeke, 2002)

Sebagai teori potensial, pandangan berbasis sumber daya unsur (RBV) saat ini bukan merupakan struktur teoretis (Priem \& Butler, 2001)

Penrose telah berperan penting bagi perkembangan berkelanjutan dari pandangan manajemen strategis berbasis sumber daya modern. Tidak setuju (Kor \& Mahoney, 2004)

\section{Model Resource Based View}

Pengembangan teori yang menyeluruh merupakan peluang bagi para peneliti manajemen strategi. Teori Resource Based View memperjelas secara komprehensif teori-teori pertumbuhan perusahaan. Dan tentu saja memberi nilai tambah bagi perkembangan management strategy

Model yang dikembangkan Joseph T Mahoney and J.Rajendran Pandian, adalah sebagai berikut: 
Integrating the diversification literature with the organizational economic literature

Integrasi dari munculnya RBV dengan organizational economics dapat memberikan nilai tambah dalam implementasi dari strategi diversifikasi, hybrid dan networks termasuk dalam koordinasi dari sumber daya.

The development of an endogenous theory of heterogeneity.

Premis dasar yang membedakan industrial organization dari strategic management asumsi dari heterogeneous perusahaan. Strategi memberikan dasar teori yang cukup kuat. Keuntungan dari strategi ini adalah pengembangan model dimana heterogeneity perusahaan adalah kreasi endogenous dari pelaku ekonomi.

Integration of the $R B V$ with strategic group analysis

Dalam kenyataannya seperti yang dikatakan McGee and Thomas 'strategic group analysis has interesting parallels with the theory of growth of the firm as first articulated by Downie, Penrose and Marris more than 20 years ago).Dapatkah sumberdaya yang tak dapat ditiru dapat menjadi sumber dalam mempertahankan keunggulan strategic group.

Integration of resources based view with industry analysis

Keunggulan bersaing adalah fungsi dari analisis industri, organizational governance dan firm effects (dalam bentuk keunggulan sumber daya dan strategies). The RBV model adalah potensial untuk menyatukan penelitian-penelitian ini untuk memperkaya dan meneguhkan teori strategi perusahaan.

Berdasarkan uraian tersebut diatas maka di dalam penyusunan model yang berkaitan dengan Resource Based View, harus memperhatikan:

1. Konsep dasar yang menyatakan bahwa kunci dari keberhasilan sumber daya terletak pada keunggulan bersaing.

2. Nilai hubungan timbal balik kompleks antara sumber daya manusia perusahaan dan sumbersumber daya lain nya, fisik, finansial, hukum, dan faktor lainnya.

3. Nilai kompetitif untuk meningkatkan kemampuan strategisnya.

4. Keuntungan dari pengoptimalan human capital.

5. Keunggulan sumber daya manusia memberi kontribusi yang tinggi atas keunggulan bersaing.
6. Dalam analisis lingkungan internal ,faktor fungsi bisnis akan sangat mempengaruhi.

7. Membuat sesuatu yang unik dan tidak mudah ditiru agar dapat memperkuat keunggulan bersaing.

8. Human resources harus diperkuat dengan ikut sertanya dalam kepemilikan perusahaan agar loyalitas dan kompetensinya meningkat yang pada gilirannya akan dapat meningkatkan keunggulan bersaing.

Analisis strategis adalah fitur kunci dari manajemen strategis. Dalam penelitian manajemen strategis, telah terjadi pergeseran dari fokus pada produk perusahaan menjadi fokus pada faktor internal dalam hal sumber daya dan kemampuan (Szymaniec-Mlicka, 2014).

Penrose menggambarkan RBV perusahaan sebagai kumpulan sumber daya yang harus terus dikembangkan agar perusahaan mempunyai karakteristik unik (Brahma \& Chakraborty, 2011).

Strategi bersaing suatu perusahaan sangat penting untuk memperoleh keunggulan bersaing dan untuk meningkatkan kinerja perusahaan. Hubungan antara struktur organisasi, strategi bersaing, dan kinerja perusahaan biasanya dianalisis dengan menggunakan pendekatan kontingensi.. (Pertusa-Ortega et al., 2010).

\section{SIMPULAN}

Pendekatan teori dari Joseph.Mahoney dan J.Rajendran,secara menyeluruh telah dapat menyatukan berbagai pendapat dari para ahli strategic management mengenai teori Resource Based View.Berdasarkan hasil analisis dari perbincangan para ahli manajemen strategi,maka ,dapat diambil kesimpulan;

Penggunaan sumberdaya memiliki banyak keunggulan potensial bagi perusahaan seperti pencapaian efisiensi yang lebih besar dan selanjutnya biaya yang lebih rendah, peningkatan kualitas dan kemungkinan pangsa pasar serta profitabilitas yang lebih besar.

Pendekatan analitis yang disebut Resource Based View (RBV) menekankan peningkatan keunggulan bersaing yang berasal dari sumber daya strategis organisasi . Keunggulan bersaing (competitive advantage) memungkinkan perusahaan memperoleh kinerja unggul .

Inti dari Resource Based View adalah bahwa perusahaan berbeda secara fundamental karena memiliki seperangkat sumberdaya yang berbeda 
Pencapaian keunggulan bersaing yang paling efektif adalah dengan menggunakan kompetensi perusahaan. Pendekatan Resource Based menekankan pentingnya sumberdaya internal untuk mencapai keunggulan bersaing yang berkelanjutan. Perspektif ini menyatakan bahwa kinerja perusahaan adalah fungsi dari seberapa baik manajer membangun organisasinya dalam menangani sumber daya yang bernilai, langka, sulit ditiru dan sulit digantikan Perusahaan dengan kompetensi yang bernilai dan langka akan menghasilkan keunggulan bersaing yang lebih besar dibandingkan pesaingnya, yang selanjutnya menghasilkan kinerja keuangan superior. Keunggulan bersaing dan kinerja yang dihasilkan perusahaan merupakan konsekuensi dari sumberdaya khusus dan kompetensi yang dimiliki. Dengan demikian dapat dikatakan bahwa perusahaan harus memiliki kemampuan untuk mengkoordinasikan sumber daya strategis dengan baik, sebab merupakan kunci dalam membangun kompetensi dan pada akhirnya pencapaian kinerja yang tinggi.

Namun demikian perlu kiranya untuk melengkapi teori Resource Based View ini dengan perkembangan ilmu masa kini,misalnya memperkaya dengan pendekatan knowledge management,juga didalam unsur yang dapat memperkuat kompetensi inti,maka unsur keikutsertaan karyawan dalam kepemilikan perusahaan dapat dipertimbangkan sebagai motivator untuk lebih meningkatkan loyalitas dan kompetensi sumber daya manusia yang akan berkaitan langsung dengan pencapaian keunggulan bersaing.

Pengertian sumber daya ditinjau berbagai perspektif membuka peluang yang besar untuk penelitian selanjutnya dalam rangka mengidentifikasikan pencapaian keunggulan bersaing.

\section{DAFTAR PUSTAKA}

Abu Bakar, L. J., \& Ahmad, H. (2010). Assessing the relationship between firm resources and product innovation performance: A Resource Based view. Business Process Management Journal, 16(3),420-435.

https://doi.org/10.1108/14637151011049430

Andersén, J. (2010). Resource based competitiveness: managerial implications of the resource $\square$ based view. Strategic Direction, 26(5), 3-5. https://doi.org/10.1108/02580541011035375

Brahma, S., \& Chakraborty, H. (2011). From Industry to Firm Resources: Resource Based View of Competitive Advantage. The IUP Journal of Business Strategy, 2, 7-21.
Frączkiewicz-Wronka, A., \& Szymaniec, K. (2012). Resource Based View and resource dependence theory in decision making process of public organisation - research fi ndings. Management, 16(2), 16-29. https://doi.org/10.2478/v10286$012-0052-2$

Joseph T Mahoney, J. R. P. (1992). The Resource Based View Within The Conversation of Strategic Management. Strategic Management Journal, 13, 363-380.

Kor, Y. Y., \& Mahoney, J. T. (2004). Edith Penrose's (1959) Contributions to the Resource Based View of Strategic Management. Journal of Management Studies, 41(1), 183-191. https://doi.org/10.1111/j.1467-

6486.2004.00427.x

Md Husin, M., \& Haron, R. (2020). Micro, small and medium enterprises' competitiveness and microtakāful adoption. ISRA International Journal of Islamic Finance, 12(3), 367-380. https://doi.org/10.1108/IJIF-03-2019-0038

Pertusa-Ortega, E. M., Molina-Azorín, J. F., \& ClaverCortés, E. (2010). Competitive strategy, structure and firm performance: A comparison of the Resource Based view and the contingency approach. Management Decision, 48(8), 12821303. https://doi.org/10.1108/00251741011076799

Portillo-Tarragona, P., Scarpellini, S., Moneva, J. M., Valero-Gil, J., \& Aranda-Usón, A. (2018). Classification and measurement of the firms' resources and capabilities applied to ecoinnovation projects from a Resource Based view perspective. Sustainability (Switzerland), 10(9). https://doi.org/10.3390/su10093161

Priem, R. L., \& Butler, J. E. (2001). Is the Resource Based for Strategic Management Perspective Research? Academy of Management Review, 26(1), 22-40.

Rugman, A. M., \& Verbeke, A. (2002). Edith Penrose's contribution to the Resource Based view of strategic management. Strategic Management Journal, 23(8), 769-780. https://doi.org/10.1002/smj.240

Runyan, R. C., Huddleston, P., \& Swinney, J. L. (2007). A Resource Based view of the small firm: Using a qualitative approach to uncover small firm resources. Qualitative Market Research, 10(4), 390-402. https://doi.org/10.1108/13522750710819720 
454 Coopetition, Vol 12, Nomor XII, November 2021,

(E-ISSN : 2615-4978, P-ISSN : 2086-4620)

Szymaniec-Mlicka, K. (2014). Resource Based view in strategic management of public organizations

- a review of the literature. Management, 18(2), 19-30. https://doi.org/10.2478/manment-20140039 